\title{
Interaction between substance $P$ and gastrin-releasing peptide on thyrotropin secretion by rat pituitary in vitro
}

E.G. Moura ${ }^{1}$,

C.V.M. Santos ${ }^{1}$

R.M.M. Santos ${ }^{2}$ and

C.C. Pazos-Moura²

\author{
1Departamento de Ciências Fisiológicas, Instituto de Biologia, \\ Universidade do Estado do Rio de Janeiro, Rio de Janeiro, RJ, Brasil \\ ${ }^{2}$ Laboratório de Fisiologia Endócrina, Instituto de Biofísica Carlos Chagas Filho, \\ Universidade Federal do Rio de Janeiro, Rio de Janeiro, RJ, Brasil
}

\section{Correspondence \\ E.G. Moura \\ Departamento de Ciências \\ Fisiológicas \\ Instituto de Biologia, UERJ \\ Av. 28 de Setembro, 87 \\ 20550-030 Rio de Janeiro, RJ \\ Brasil \\ Fax: +55-21-587-6129 \\ E-mail: egmoura@uerj.br}

Research supported by CNPq (No. 520967/94-1), CAPES,

SR-2 UERJ, FUJB and CEPG-UFRJ.

Received December 9, 1998

Accepted June 7, 1999

\section{Abstract}

The effect of substance P (SP) on thyrotropin (TSH) secretion is controversial. In this study we evaluated the effect of SP on TSH secretion by hemipituitaries of 3-month-old Wistar rats in vitro and its interaction with gastrin-releasing peptide (GRP) at equimolar concentrations $(1 \mu \mathrm{M}$ and $10 \mu \mathrm{M})$. TSH release was measured under basal conditions and $30 \mathrm{~min}$ after incubation in the absence or presence of SP, GRP or both peptides. Pituitary TSH content was also measured in the pituitary homogenate after incubation. SP at both concentrations caused a significant $(\mathrm{P}<0.05)$ increase in TSH secretion compared with all other groups, which was approximately $60 \%(1 \mu \mathrm{M})$ and $85 \%$ $(10 \mu \mathrm{M})$ higher than that of the control group $(23.3 \pm 3.0 \mathrm{ng} / \mathrm{ml})$. GRP at the lower concentration did not produce a statistically significant change in TSH secretion, whereas at the concentration of $10 \mu \mathrm{M}$ it produced a $50 \%$ reduction in TSH. GRP co-incubated with substance $\mathrm{P}$ completely blocked the stimulatory effect of SP at both concentrations. Pituitary TSH content decreased in the SP-treated group compared to controls $(0.75 \pm 0.03 \mu \mathrm{g} /$ hemipituitary $)$ at the same proportion as the increase in TSH secretion, and this effect was also blocked when GRP and SP were co-incubated. In conclusion, in an in vitro system, SP increased TSH secretion acting directly at the pituitary level and this effect was blocked by GRP, suggesting that GRP is more potent than SP on TSH secretion, and that this inhibitory effect could be the predominant effect in vivo.

\section{Introduction}

Substance $\mathrm{P}$ (SP) is a tachykinin peptide with 11 amino acids which is expressed in numerous neural and endocrine tissues (1). The highest SP concentration is found in rat and primate hypothalamic extracts (2-5). A high density of immunoreactive SP is pres-
Key words

- Substance P

- Thyrotropin

- Gastrin-releasing peptide 
of substance $P$ in the paraventricular nucleus (PVN) and also in the median eminence of rats (6). Furthermore, in the median eminence, SP-like-immunoreactive fibers are present in abundance, and nerve terminals of SP fibers contact the basal lamina of capillaries in the hypophyseal portal circulation (7). These data support the view that substance $P$ plays a role in the regulation of the anterior pituitary, acting as a hypothalamic neurohormone and reaching the pituitary through the portal circulation $(4,7)$.

However, SP has also been detected by immunocytochemistry within thyrotrophs, lactotrophs and somatotrophs of the rat anterior pituitary $(8,9)$ as well as within a subset of thyrotrophs in the human pituitary (10). The presence of preprotachykinin A mRNA in the anterior pituitary gland (11) suggests that SP is synthesized in the gland. Therefore, it is likely that, in addition to hypothalamic SP, pituitary hormone secretion may be regulated by SP produced within the gland in an autocrine/paracrine manner.

In addition, a direct effect of SP is supported by the finding of specific high affinity binding sites for SP in the pituitary gland $(12,13)$ that have been characterized as type 1 neurokinin receptors, whose endogenous ligand is SP (13). These receptors, similar to those of hypothalamic hormones, such as TRH (thyrotropin-releasing hormone), stimulate phosphatidylinositol 4,5-biphosphatespecific phospholipase $\mathrm{C}$ activity (14).

SP isolated from hypothalamic extracts has been shown to have several effects on anterior pituitary secretion (1). Substance P injected into the lateral ventricle of female Rhesus monkey increased prolactin and decreased growth hormone concentrations in serum (15), while in the rat these effects were variable, perhaps depending on the concentration employed (16-20). The effect on LH is controversial and depends on the species studied, the route of administration and sex-steroid hormonal status (16-18,21). SP decreased ACTH secretion and stimulat- ed arginine-vasopressin secretion in rats (22).

The action of SP upon thyrotropin (TSH) secretion is also controversial. While Mitsuma and Nogimori (23) found a decrease in serum TSH and a blockade of TRH- or cold exposure-induced TSH-release when SP was injected intravenously into male rats, Arisawa et al. $(24,25)$ found no effect in vivo when SP was injected either intravenously or into the third cerebral ventricule, or in vitro when the peptide was added to the medium for dispersed anterior pituitary cells.

We have shown that two bombesin-like peptides, neuromedin B (NB) (26) and gastrin-releasing peptide (GRP) (27), inhibit TSH secretion. NB content $(28,29)$ and action $(26,30)$ at the pituitary gland level are influenced by thyroid status. Hypothyroidism decreases, while thyroid hormone increases pituitary NB and its mRNA content $(28,29)$. Also, SP concentration in the anterior pituitary is modified by thyroid status. Thyroidectomy increases, while hyperthyroidism decreases the content of the peptide and its prohormone-encoding mRNA (11, 31,32 ), and the same occurs in the central nervous system of hypo- and hyperthyroid rats (33). Taken together, these data raise the possibility that bombesin-like peptides and SP interact to modulate TSH secretion. There are some SP analogs that function as SP and GRP or bombesin antagonists in several biological systems $(34,35)$. In the present study we tested the effect of SP and its interaction with GRP on TSH secretion in vitro.

\section{Material and Methods}

\section{Animals}

Three-month-old male Wistar rats (250$280 \mathrm{~g}$ ) were housed under controlled conditions of temperature $\left(24 \pm 1^{\circ} \mathrm{C}\right)$ and light $(12$ $\mathrm{h}$ light starting 7 a.m.). The animals were bred in our animal facilities. 


\section{In vitro experiment}

The animals were sacrificed by decapitation. Pituitaries were quickly dissected out, the anterior pituitary was separated from the posterior pituitary, and each anterior hemipituitary was immediately transferred to a tube containing $1.0 \mathrm{ml}$ of 199 medium (Sigma Chemical Co., St. Louis, MO, USA) plus $0.1 \%$ bacitracin and $10 \mathrm{mM}$ HEPES

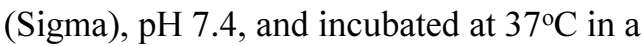
Dubnoff metabolic shaker. In two sets of experiments, the glands were divided into four groups of 10 hemipituitaries each: 1) control, 2) SP, 3) GRP and 4) SP + GRP. Both peptides (purchased from Peninsula Laboratories, Palo Alto, CA, USA) were added to a final concentration of $1 \mu \mathrm{M}$ or 10 $\mu \mathrm{M}$. After 30 min of pre-incubation the medium was removed, the hemipituitaries were resuspended in $1 \mathrm{ml}$ of fresh medium and after $30 \mathrm{~min}$ an aliquot was collected for measurement of basal TSH. Then, $10 \mu \mathrm{l}$ of medium alone or the peptide(s) corresponding to each group was added to each tube. After $30 \mathrm{~min}$ another aliquot was collected to measure post-stimulus TSH. The values are reported as the difference between stimulated TSH and basal TSH ( $\Delta \mathrm{TSH})$. Each hemipituitary was homogenized in phosphate-buffered saline containing $1 \%$ bovine serum albumin (Sigma), $\mathrm{pH}$ 7.6, for measurement of intrapituitary TSH.

\section{Radioimmunoassay}

TSH concentrations in the incubation medium and homogenates were determined by radioimmunoassay using kits supplied by the National Institute of Diabetes, Digestive and Kidney Diseases and are reported in terms of the reference preparation provided (RP2).

\section{Statistical analysis}

Data are reported as means \pm SEM. One- way analysis of variance (ANOVA) followed by the Newman-Keuls multiple comparison test was used for data analysis, with the level of significance set at $\mathrm{P}<0.05$.

\section{Results}

As expected, there was no difference in basal TSH secretion amongst the groups studied (data not shown). The incubation with 1 $\mu \mathrm{M}$ substance $\mathrm{P}$ caused a significant $(\mathrm{P}<0.05)$ increase in TSH secretion compared with all other groups studied, causing approximately a 59\% higher TSH release than the control group (Figure 1, panel A). GRP at the same concentration produced a smaller nonsignificant decrease in TSH secretion, but when co-incubated with substance P, GRP completely blocked the stimulatory effect of substance P (Figure 1, panel A). Incubation with the peptides at the ten-fold higher concentration $(10 \mu \mathrm{M})$ produced a greater release of TSH by the pituitaries incubated with SP $(87 \%, P<0.001)$, while GRP-incubated pitu-

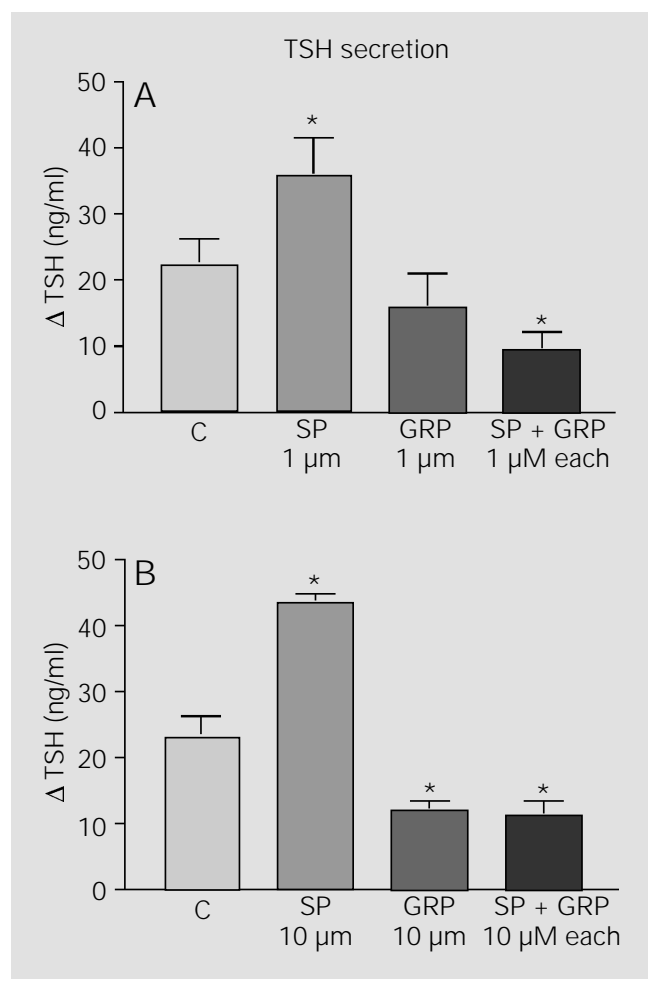

Figure 1 - Thyrotropin (TSH) release from hemipituitaries incubated in the presence of medium alone (control, C) or $1 \mu \mathrm{M}$ (Panel A) or $10 \mu \mathrm{M}$ (Panel B) gastrin-releasing peptide (GRP), substance $\mathrm{P}(\mathrm{SP})$ or both. $\Delta=$ Difference in medium TSH before and after peptide addition. Data are reported as means \pm SEM for 3 experiments. $* \mathrm{P}<0.05$ compared to control (ANOVA followed by NewmanKeuls multiple comparison test). 
Figure 2 - Thyrotropin (TSH) content of hemipituitaries incubated in the presence of medium alone (control, C) or $1 \mu \mathrm{M}$ (Panel A) or $10 \mu \mathrm{M}$ (Panel B) gastrin-releasing peptide (GRP), substance $P$ (SP) or both. Data are reported as means \pm SEM for 3 experiments. $* \mathrm{P}<0.05$ compared to control (ANOVA followed by Newman-Keuls multiple comparison test). itaries had a $50 \%$ lower TSH concentration in the medium $(\mathrm{P}<0.001)$. Again, GRP coincubated with SP blocked the stimulatory effect of the peptide (Figure 1, panel B).

The TSH content in the pituitaries incubated with both peptides at the concentrations of $1 \mu \mathrm{M}$ and $10 \mu \mathrm{M}$ was lower in the SP group and inversely proportional to the observed increase in TSH secretion $(63 \%$ at 1 $\mu \mathrm{M}$ and $85 \%$ at $10 \mu \mathrm{M}$ ), an effect which was also inhibited by co-incubation with GRP (Figure 2, panels A and B). GRP alone did not affect pituitary TSH concentration at 1 $\mu \mathrm{M}$, but TSH concentration was $25 \%$ higher when GRP was added at $10 \mu \mathrm{M}$.

\section{Discussion}

We studied the effect of substance $\mathrm{P}$ on TSH secretion and its interaction with GRP, a bombesin-like peptide, which we have previously shown to inhibit TSH secretion in vitro at the concentration of $10 \mu \mathrm{M}$ (27). In the present study, we also used a 10-times lower GRP concentration. At this concentration GRP did not affect TSH secretion by

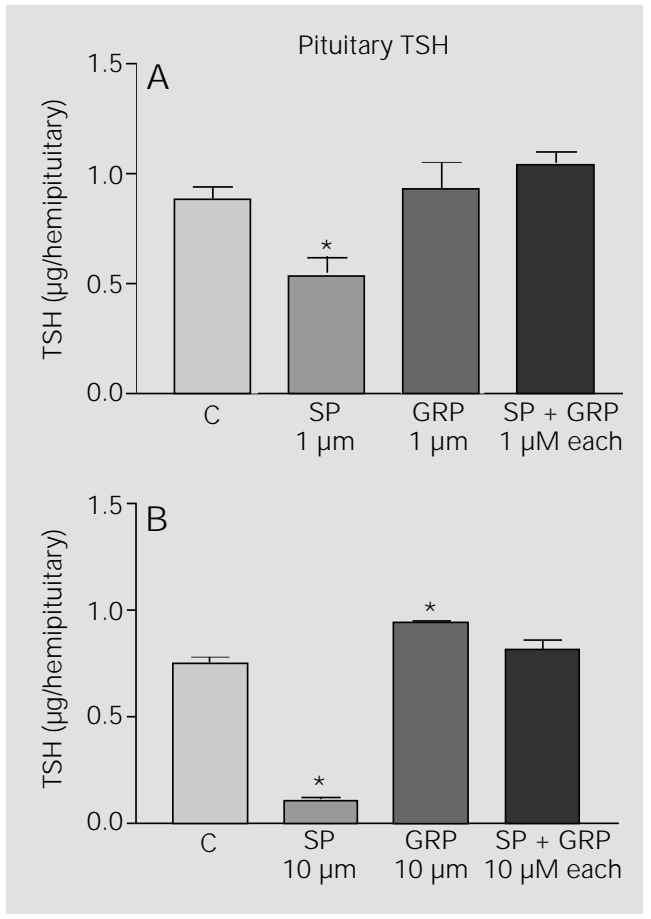

isolated pituitaries. The concentration of 1 $\mu \mathrm{M}$ substance $\mathrm{P}$ was chosen because in initial experiments (data not shown) we showed that $1 \mu \mathrm{M}$ was the minimum SP concentration able to increase TSH secretion. The other concentrations studied were 1, 10 and $100 \mathrm{nM}$.

The inhibitory effect of $10 \mu \mathrm{M}$ GRP on TSH secretion by isolated pituitaries was maintained even when SP was co-incubated at the concentration that caused an $87 \%$ higher TSH release into the medium, when $\mathrm{SP}$ was incubated alone. Even at the lower molarity, at which GRP did not change TSH secretion and SP-incubated pituitaries presented a 59\% higher TSH secretion, this effect was blocked by GRP co-incubation. These data suggest that GRP can function as an SP antagonist in the control of TSH secretion and in this case it is more potent than SP. It is unlikely that this blockade could be due to a summation of opposite effects since at both concentrations studied pituitaries coincubated with both peptides showed lower TSH secretion than the control group. More experiments are needed to elucidate the mechanisms of this antagonism.

There are reports of interaction of SP and bombesin-like peptides, but none was related to TSH secretion. The contractile effect of bombesin on the guinea-pig isolated taenia coli (35) was antagonized by SP antagonists. This observation raised the possibility that bombesin and SP interact with each other's receptors (35). This also may be the case for GRP in view of the structural homology between bombesin and GRP. However, it is also possible that GRP and SP have opposite and independent effects on TSH release, GRP being more potent than SP.

Intraventricular or intravenous administration of SP failed to alter TSH release in male rats, but stimulated TSH secretion in estrogen-primed ovariectomized rats (25). However, Mitsuma and Nogimori (23) found a suppressive effect of SP injected $i v$ on TSH release in male rats. The discrepancy be- 
tween the results of those experiments might be related to the different SP doses employed and to the fact that their results were obtained in vivo, while ours were obtained in vitro. Our study establishes that substance $\mathrm{P}$ has a direct stimulatory effect at the pituitary level. The fact that Arisawa et al. (18) did not find any effect of SP on pituitary cells cultured overnight might be related to differences in the in vitro systems utilized or to different times of incubation. Vijayan and McCann (16) also did not find any effect of SP on TSH secretion using a methodological approach similar to ours, however, they studied ovariectomized female rats. Therefore, it appears that the sex and sex-hormone status of the animal influence the TSH response to SP. In support of this hypothesis, it has been demonstrated that the distribution of substance $\mathrm{P}$ in different pituitary cell populations is sexually dimorphic (36).

The observed direct effect of exogenous SP on TSH secretion agrees with the presence of SP receptors in the pituitary gland
(12-14), which, physiologically, might be activated by hypothalamic SP or the locally produced peptide, which has been localized within the thyrotroph by immunocytochemistry $(8,10)$.

Several lines of evidence suggest an interplay between SP and NB/GRP in TSH secretion. Both peptides have been shown to be present in the thyrotrophs, and they have opposite effects on TSH secretion, with SP increasing it while NB and GRP decrease it $(26,27,30)$. Their pituitary levels are modified in opposite directions by thyroid hormone. Pituitary SP content decreases, while NB content increases with thyroxine administration $(28,29,31,32)$ and in hypothyroidism the reverse occurs for both peptides $(30,31)$. We have shown in the present paper that GRP antagonized the effect of SP on TSH secretion. Therefore, it is tempting to propose that these peptides could play a role as local regulators in the inhibition of TSH secretion caused by thyroid hormones, modulating each other's effects.

\section{References}

1. Aronin N, Coslovsky R \& Leeman SE (1986). Substance P and neurotensin. Annual Review of Physiology, 48: 537-549.

2. Ljungdahl A, Hökfelt T\& Nilsson G (1978). Distribution of substance P-like immunoreactivity in the central nervous system of the rat cell bodies and nerve terminals. Neuroscience, 3: 861-880.

3. Panula $\mathrm{P}$, Yang H-T \& Costa E (1984). Comparative distribution of bombesin/ GRP- and substance P-like immunoreactive in rat hypothalamus. J ournal of Comparative Neurology, 224: 606-617.

4. Hökfelt $T$, Pernow B, Nilsson $G$, Weterburg L, Goldstein M \& J effcoate S (1978). Dense plexus of substance P immunoreactive nerve terminals in eminentia medials of the primate hypothalamus. Proceedings of the National Academy of Sciences, USA, 75: 1013-1015.

5. Mai J, Stephens P, Hope A \& Cuello A (1986). Substance $P$ in the human brain. Neuroscience, 17: 709-739.

6. J essop DS, Chowdrey HS \& Lightman SL
(1990). Substance P and substance K in the median eminence and paraventricular nucleus of the rat. Neuropeptides, 17: 135-140.

7. Tsuruo Y, Kawano H, Nishiyama T, Hisano S \& Daikoku S (1983). Substance P-like immunoreactive neurons in the tuberoinfundibular area of rat hypothalamus. Light and electron microscopy. Brain Research, 289: 1-9.

8. De Palatis LR, Fiorindo RP \& Ho RH (1981). Substance $P$ immunoreactivity in the anterior pituitary gland of the guinea pig. Endocrinology, 110: 282-284.

9. Morel G, Chayvialle J A, Kerdelhue B \& Dubois PM (1982). Ultrastructural evidence for endogenous substance P-like immunoreactivity in the rat pituitary gland. Neuroendocrinology, 35: 86-92.

10. Roth $K \&$ Krause J (1990). Substance $P$ is present in a subset of thyrotrophs in the human pituitary. J ournal of Clinical Endocrinology and Metabolism, 71: 1089-1095.

11. J onassen J A, Mullikin-Kilpatrick D,
McAdam A \& Leeman SE (1987). Thyroid hormone status regulates preprotachykinin: a gene expression in the male rat anterior pituitary. Endocrinology, 121: 1555-1561.

12. Kedelhue B, Tartar A, Lenoir V, El Abded A, Hublau P \& Millar R (1985). Binding studies of substance $P$ anterior pituitary binding sites - changes in substance $P$ binding sites during the rat estrous cycle. Regulatory Peptides, 10: 133-143.

13. Larsen PJ , Mikkelsen J D \& Sæmark T (1989). Binding of an iodinated substance $\mathrm{P}$ analog to a NK-1 receptor on isolated cell membranes from rat anterior pituitary. Endocrinology, 124: 2548-2557.

14. Mau SE, Larsen PJ, Mikkelsen JA \& Sæmark T (1990). Substance P and related tachykinins induce receptor-mediated hydrolysis of polyphosphoinositides in the rat anterior pituitary. Molecular and Cellular Endocrinology, 69: 69-78.

15. Eckstein N, Wehrenberg WB, Louis K, Carme $P$, Zimmerman EA, Frantz $A \&$ 
Ferin M (1980). Effects of substance $P$ on anterior pituitary secretion in the female Rhesus monkey. Neuroendocrinology, 31: 338-342.

16. Vijayan E \& McCann SM (1979). Effect of substance $P$ and neurotensin on growth hormone and thyrotropin release in vivo and in vitro. Life Sciences, 26: 321-327.

17. Picanço-Diniz DLW, Valença $M$, Franci $C R$ \& Antunes-Rodrigues J (1990). Role of substance $P$ in the medial preoptic area in the regulation of gonadotropin and prolactin secretion in normal or orchidectomized rats. Neuroendocrinology, 51: 675-682.

18. Arisawa M, Snyder GD \& McCann SM (1990). Stimulatory role of substance P on gonadotropin release in ovariectomized rats. Neuroendocrinology, 51: 523-529.

19. Arisawa M, Snyder GD, Yu W, De Palatis LR, Ho RH, Xu R \& McCann SM (1990). Physiologically significant inhibitory hypothalamic action of substance $P$ in prolactin release in the male rat. Neuroendocrinology, 52: 22-27.

20. Kato Y, Chihara K, Ohgo S, Iwasaki Y, Abe H \& Imura H (1976). Growth hormone and prolactin release by substance $P$ in rats. Life Sciences, 19: 441-446.

21. Wormald P, Millar R \& Kerdelhue B (1989). Substance $P$ receptors in human pituitary, a potential inhibitor of luteinizing hormone secretion. J ournal of Clinical Endocrinology and Metabolism, 69: 612-615.

22. Chowdrey $\mathrm{H}$, Jessop $\mathrm{D} \&$ L Lightman $\mathrm{S}$ (1990). Substance $P$ stimulates arginine vasopressin and inhibits adrenocorticotropin release in the rat. Neuroendocrinology, 52: 90-93.

23. Mitsuma T\& Nogimori T (1984). Effects of substance $\mathrm{P}$, angiotensin II, oxotremo- rine and prostaglandin $D_{2}$ on thyrotropin secretion in rats. Hormone Research, 19: 176-184.

24. Arisawa M, Snyder GD \& McCann SM (1989). Effect of substance P on thyrotropin secretion from the pituitary gland in the rat. Peptides, 10: 763-766.

25. Arisawa M, Makino T, McCann SM \& Izuka R (1989). Effect of estrogen on the response of thyroid stimulating hormone to substance $P$ in rats. Endocrinologia J aponica, 36: 899-903.

26. Rettori V, Pazos-Moura CC, Moura EG, Polak J \& McCann SM (1992). Role of neuromedin $B$ in the control of the release of thyrotropin in hypothyroid and hyperthyroid rats. Proceedings of the $\mathrm{Na}$ tional Academy of Sciences, USA, 89: 3035-3039.

27. Santos CV, Pazos-M oura CC \& Moura EG (1995). Effect of gastrin-releasing peptide (GRP) and GRP antagonists on TSH secretion from rat isolated pituitaries. Life Sciences, 57: 911-915.

28. Steel J H, Van Noorden S, Ballesta J, Gibson SJ , Ghatei MA, Burrin J , Leonhardt U, Domin J , Bloom SR \& PolakJ M (1988). Localization of $7-B_{2}$, neuromedin $B$ and neuromedin $U$ in specific cell types of rat, mouse and human pituitary and extrapituitary tumors. Endocrinology, 122: 270282.

29. J ones PM, Withers DJ, Ghatei MA \& Bloom SR (1992). Evidence for neuromedin B synthesis in the rat anterior pituitary gland. Endocrinology, 130: 1829-1836.

30. Pazos Moura CC, Moura EG, Rettori V, Polak J \& McCann SM (1996). Role of neuromedin $B$ in the in vitro thyrotropin release in response to thyrotropin-releas- ing hormone (TRH) from anterior pituitaries of eu, hypo and hyperthyroid rats. Proceedings of the Society for Experimental Biology and Medicine, 211: 353-358.

31. J ones PM, Ghatei MA, Steel J , O'Halloran D, Gon G, Legon S, Burrin J M, Leonhardt U, PolakJ M \& Bloom SR (1989). Evidence for neuropeptide $Y$ synthesis in the rat anterior pituitary and the influence of thyroid hormone status: comparison with vasoactive intestinal peptide, substance $P$ and neurotensin. Endocrinology, 125: 334-341.

32. Aronin N, Morency K, Leeman SE, Braverman LE \& Coslovsky R (1984). Regulation by thyroid hormone of the concentration of substance $P$ in the rat anterior pituitary. Endocrinology, 114: 21382141.

33. Savard P, Merand Y, Dipaolo T \& Dupont A (1983). Effects of thyroid state on serotonin, 5-hydroxyindoloacetic acid and substance $\mathrm{P}$ contents in discrete brain nuclei of adults rats. Neuroscience, 10: 13991404

34. J ensen RT, J ones SW, Lu Y-A, Xu J -C, Folkers K \& Gardner JD (1984). A synthetic peptide that is a bombesin receptor antagonist. Biochimica et Biophysica Acta, 804: 181-191.

35. Folkers K, Häkanson R, Hörig J , Xu J -C \& Leander S (1984). Biological evaluation of substance $P$ antagonists. British J oumal of Pharmacology, 83: 449-456.

36. Brown ER, Roth KA \& Krause JE (1991). Substance $P$ is distributed between somatotrophs and thyrotrophs in a sexually dimorphic manner in rat. Proceedings of the National Academy of Sciences, USA, 88: 1222-1226. 